УДК 517.9; 539.3; 517.5

\section{Т.Н. Бобылева}

НИУ МГСУ

\section{АКТУАЛЬНЫЕ \\ ПРИКЛАДНЫЕ \\ ИССЛЕДОВАНИЯ КАФЕДРЫ ВЫСШЕЙ МАТЕМАТИКИ МГСУ}

Приведен обзор некоторых научных исследований, ведущихся преподавателями кафедры в области дифференциальных уравнений в частных производных, механики сплошной среды, теории вероятностей и математической статистики, теории функций, функционального анализа, топологии, теории полимерных композитов, имеющих большие возможности применения для составления и решения задач строительства, техники и экономики

Ключевые слова: научные исследования кафедры, механика сплошной среды, дифференциальные уравнения в частных производных, дробный дифференциальный оператор, прочность бетона, собственные колебания, случайные процессы, гамильтоновы матрицы
T.N. Bobyleva

MGSU

\section{CURRENT APPLIED INVESTIGATIONS OF THE DEPARTMENT OF HIGHER MATHEMATICS OF MGSU}

The article presents an overview of some research works done by the academic staff of the Department in the field of differential equations, solid mechanics, probability theory and mathematical statistics, theory of functions of real and complex variable, functional analysis, topology, the theory of polymer composites having theoretical and practical interest, which leads to wide possibilities of application of these researches for formulation and solution of model problems of construction, technology and economics. In particular, we considered the problem of planar non-rotational fluid flow with a free boundary, discrete kinetic model of rarefied gas, the Burgers-Huxley equation of advection-diffusion fractional order. We studied the stress concentrators due to the geometry of the boundary and coupling elements made of materials with different physical properties, stress relaxation in concrete, free vibrations of isotropic hollow balls. The issues of loaded systems' research arise frequently in practice in the problems with lumped loads. Extremum problems were considered, in particular, in the loaded space of Jacobi, extremum problems for analytic functions of some classes, the use of the duality of linear spaces applied to extremum problems of complex analysis. The researches on methods of teaching mathematics in technical universities were performed.

Key words: scientific researches of the Department, continuum mechanics, partial differential equations, fractional differential operator, concrete strength, natural vibrations, stochastic processes, Hamiltonian matrix
В данной статье представлены актуальные направления в области математики и механики, с которыми связана научно-исследовательская деятельность преподавателей кафедры высшей математики Московского государственного строительного университета.

Дифференциальные уравнения в частных производных широко применяются при решении технических задач. В частности, нелинейное уравнение Бюргерса - Хаксли [1] используется, например, в гидродинамике для описания автоволны переключения в сегнетоэлектриках и магнетиках, распространения фронта горения в бикфордовом шнуре. В [1] дана постановка и численное решение задачи Коши уравнения Бюргерса - Хаксли с начальным усло-
The article presents current trends in the field of mathematics and mechanics involved in the research activities of the academic staff of the Department of Higher Mathematics of Moscow State University of Civil Engineering.

Partial differential equations are widely used in the solution of technical problems. So nonlinear Burgers-Huxley equation [1] is used in hydrodynamics, as well as, for example, for describing autowave of switching in ferroelectrics and magnetic materials, propagation of the combustion front in the Bickford cord.

The formulation and numerical solution of the Cauchy problem of the Burgers-Huxley equation are given in [1], with the initial condition, which is a 
вием, являющимся стационарным нормальным случайным процессом. Так же численно в [2] решена система уравнений Карлемана. В [3] рассматривается вопрос о перераспределении энергии для усиления второй гармонической составляющей акустических волн в средах с избирательным поглощением.

В последние годы в мире неуклонно растет интерес к дифференциальным уравнениям дробного порядка [4], которые все шире используются в механике, физике, химии, различных инженерных приложениях. В [5, 6] изучено решение краевой задачи для такого уравнения адвекции-диффузии.

Фотоупругость - это появление оптической анизотропии в изотропных твердых телах, на которые действуют механические напряжения. Данное явление часто используется для изучения сложных механических конструкций, находящихся под нагрузкой. В статьях [7-13] с помощью метода фотоупругости исследуется напряженно-деформированное состояние конструкций на моделях с угловым вырезом границы, сооружений со сложными областями сопряжения материалов, имеющих разные механические свойства, а также результат действия вынужденных деформаций, разрывных по поверхности контакта.

Самый актуальный материал в строительной промышленности - это бетон. Изучению его свойств посвящено большое количество работ в России и за рубежом. В [14-17] решена задача старения изогнутого железобетонного бруса с учетом структурных повреждений бетона и арматуры при различных способах нагружения.

Постоянно расширяется область применения пьезокерамических материалов - это, например, излучатели и приемники звука в гидроакустике, элементы зажигания, пьезотрансформаторы, пьезоприводы, различные приборы акустоэлектроники [18]. В [19] дана прикладная теория распространения осесимметричных волн в пьезокерамических цилиндрах.

В механике пластин и оболочек существует большое количество при- stationary normal random process. Also in [2] the system of equations of Carleman is solved numerically. In [3] the question of the redistribution of energy is observed to enhance the second harmonic component of the acoustic waves in media with selective absorption.

In recent years in the world the interest in differential equations of fractional order has been steadily growing [4], which are increasingly used in mechanics, physics, chemistry, and various engineering applications. In $[5,6]$ a solution of the boundary value problem is studied for such an equation of advection-diffusion.

Photo elasticity is the appearance of optical anisotropy in isotropic solids, on which the mechanical stresses are influencing. This phenomenon is often used to study complex mechanical structures under load. In the articles [7-13] by a method of photoelastic analysis the stress-strain state of structures is investigated on the models with a corner cut border, structures with complex areas of the pairing of materials having different mechanical properties, and also the result of the forced discontinuous deformations on the contact surface.

The most relevant material in the construction industry is concrete. The study of its properties is the subject of numerous works in Russia and abroad. In [14-17] the problem of reinforced concrete curved beam aging is solved with regard to structural damage of concrete and reinforcement at various ways of loading.

The field of application of piezoelectric materials is constantly expanding - this, for example, the emitters and receivers of sound in hydroacoustics, elements of ignition, piezotransformers, drives, various devices of acoustoelectronics [18]. In [19] the applied theory of the propagation of axisymmetric waves in piezoceramic cylinders is presented.

In the mechanics of plates and shells there are a large number of applied theories based on various simplifying assumptions regarding the nature of 
кладных теорий, основанных на различных упрощающих предположениях относительно характера деформирования, но для некоторых классов граничных задач решение нужно проводить на основе полной системы трехмерных уравнений теории упругости. В [20] получено уравнение для определения частот собственных колебаний изотропных полых шаров в случае такой постановки задачи.

В теории вероятностей мартингал является абстрактной формализацией представления о последовательности справедливых игр. Это понятие играет важную роль при изучении наилучших правил остановки для большой совокупности задач [21-25]. В [26-28] нормальный закон распределения применяется в изучении планов контроля по количественному признаку при двустороннем ограничении.

Результаты работ [29-34], посвященных производным векторнозначных мер и гамильтоновым системам, находят применения: в теории оптимального управления - при аналитическом конструировании оптимальных линейных систем по квадратичному критерию качества, при решении задачи о поступательно-вращательном движении сфероидального спутника вокруг Земли, при исследовании устойчивости гамильтоновых систем методами Биркгофа, Депри Хори.

Нагруженные пространства функций необходимы при решении многих задач математической физики, вычислительной математики, теории функций и функционального анализа, в частности, в задачах с различными сосредоточенными усилиями. Для решения таких задач необходимы ряды Фурье по нагруженным ортонормированным полиномам [35-38].

Связь экстремальных задач комплексного анализа и двойственность линейных пространств рассмотрена в [3941]. Задачи оптимизации преобразуются в двойственные задачи наилучшего приближения.

В [42-45] также в области комплексного анализа доказана возможность оптимального восстановления ограниченных аналитических функций, deformation, but for some classes of boundary value problems the solution should be done on the basis of full three-dimensional system of equations of elasticity theory. In [20] the equation was obtained for determining the natural frequencies of isotropic hollow balls in case of such formulation of the problem.

In probability theory, a martingale is an abstract formalization of the concept of sequence of fair games. This concept plays an important role in the study of the best stopping rules for a large set of tasks [21-25]. In [26-28] normal distribution was applied in the study of control plans for the quantitative character under bilateral constraint.

The results of the papers [2934], devoted to vector-valued derivatives and Hamiltonian systems are finding applications in optimal control theory - in analytic design of optimal linear systems on quadratic performance criterion, in the solution of the problem of translational-rotational motion of spheroidal satellites around the Earth, in the study of stability of Hamiltonian systems by methods of Birkhoff, DepritHori.

The loaded spaces of functions are necessary for solving many problems of mathematical physics, computational mathematics, theory of functions and functional analysis, in particular, in problems with a variety of concentrated efforts. In order to solve such problems, Fourier series of loaded orthonormal polynomials are required [35-38].

The relationship of extremal problems of complex analysis and duality of linear spaces was considered in [3941]. The optimization problem is transformed into the dual problem of the best approximation.

In [42-45] also in the field of integrated analysis the possibility of optimal recovery of bounded analytic functions has been proven, these functions are specified in the unit circle of the complex plane and their first and second derivatives can be recovered by using a finite number of values of these functions. 
заданных в единичном круге комплексной плоскости, и первых и вторых производных этих функций по их значениям. Дана оценка погрешности для некоторых областей.

В [46-49] изучаются ультраметрические пространства, т.е. метрические пространства с метрикой, удовлетворяющей усиленному неравенству треугольника:

$$
d(x, z) \leq \max [d(x, y), d(y, z)] .
$$

Примеры таких пространств есть в действительном анализе, теории чисел и общей топологии. Ультраметрический анализ используется при описании в простом виде свойств некоторых сложных систем, для которых недостаточно методов вещественного анализа, это, в частности, теория спиновых стекол, динамика макромолекул и генетика.

В [50 - 53] изучаются аменабельные группы, т.е. группы, на которых существует ненулевая конечно-аддитивная мера. Она принимает конечные значения на всех подмножествах, и инвариантна относительно (правого) действия группы на себя.

Работы [54-57] посвящены новому направлению в теории полимерных материалов: получению новых полимеров не путем синтеза, а с помощью образования смесей уже известных полимеров. Получены зависимости модуля упругости полимера от молярной и объемной долей. Рассмотрены приложения к теории ползучести.

Задача о движении стрелы экскаватора решена в [58], и в [59, 60] учет и контроль логистических затрат проведен с помощью составленных новых компьютерных программ. Особо рассмотрен вопрос о показателях эффективности данных логистических процессов.

Новые методы самостоятельной работы студентов с помощью компьютеров разработаны в [61], в которых особое внимание уделяется совершенствованию процесса доступности изучаемого материала. Индивидуальный подход при составлении заданий для самостоятельной работы и, следовательно, индивидуальное планирование затрат времени на их
The authors of [46-49] studied ultrametric space, i.e. a metric space with the metrics, satisfying the strengthened triangle inequality:

$$
d(x, z) \leq \max [d(x, y), d(y, z)] .
$$

The examples of such spaces can be found in real analysis, number theory and General topology. Ultrametric analysis is used to describe simple properties of some complex systems for which inadequate methods of real analysis are not enough, which is, in particular, the theory of spin glasses, dynamics of macro-molecules and genetics.

In the articles [50 - 53] the amenable groups are studied, i.e. the groups for which a nonzero finitely additive measure exists. It takes finite values on all subsets, and it is invariant under the (right) action of group on itself.

The papers [54-57] are devoted to a new direction in the theory of polymeric materials: the preparation of new polymers not by synthesis, but with the help of mixtures formation of known polymers. The dependencies of the modulus of elasticity of the polymer from the molar and volume fractions are obtained. The applications to the creep theory are considered.

The problem of motion of a boom of the excavator is solved in [58], and in [59-60] accounting and control of 10gistics costs is undertaken using new computer programs. Especially the question about indicators of the effectiveness of these logistics processes is considered.

New methods of independent work of students using computers were developed in [61], in which special attention is paid to improving the availability of the studied material. Individual approach in the compilation of assignments for independent work and, consequently, individual planning of time for their fulfillment is required in the study of such basic courses at a technical college as mathematics, physics and chemistry. This is the content of the articles [62-63].

Mathematics is as always the basis of exact natural science, together with 
выполнение необходимы при изучении таких базовых курсов технического вуза, как математика, физика и химия. Это является содержанием статей [62-63].

Математика, как и во все времена, - основа точного естествознания, вместе с механикой является фундаментом всех технических наук, а в последние десятилетия значение математики в общей системе человеческих знаний значительно возросло. Преподаватели кафедры высшей математики НИУ МГСУ вносят большой вклад в развитие важных направлений математики и механики, их применений в различных отраслях техники и промышленности.

\section{БИБЛИОГРАФИЧЕСКИЙ СПИСОК}

1. Васильева О.A. Исследование некоторых вероятностных характеристик решения задачи Коши для уравнения Бюргерса-Хаксли // Труды МАИ. 2014. Вып. 78. Режим доступа: http://www.mai.ru/science/ trudy/. Дата обращения: 07.07.2015.

2. Васильева О.А. Численное исследование системы уравнений Карлемана // Вестник МГСУ. 2015. № 6. C. 7-15.

3. Андреев В.Г., Васильева О.А., Лапшин Е.А., Руденко О.В. Процессы генерации второй гармоники и вырожденного параметрического усиления в среде с селективным поглощением // Акустический журнал. 1985. Т. ХХXI. Вып. 1. C. $12-16$.

4. Miller K.S., Ross B. An Introduction to the Fractional Calculus and Fractional Differential Equations. New York : John Wiley and Sons. 1993. $384 \mathrm{p}$.

5. Aleroev T.S. The eigenvalues of a boundary value problem for a fractional-order differential operator // Differential Equations. 2000. Vol. 36. No. 10. Pp. 1569-1570.

6. Исаева Л.М., Алероев Т.С. Качественные свойства одномерного дробного дифференциального уравнения адвекции-диффузии // Вестник МГСУ. 2014. № 7. С. 28-33.

7. Савостьянов

B.H., Фриштер Л.Ю. Моделирование кусочно-однородной задачи механики деформируемого твердого тела // Известия Российской академии наук. Механика твердого тела. 1993. № 6. C. 38 . the mechanics it is the foundation of all engineering sciences.

The value of mathematics in the general system of human knowledge has greatly increased in recent decades. The teachers of Department of higher mathematics, national research University of civil engineering contribute to the development of important areas of mathematics, mechanics and their applications in various branches of engineering and industry.

\section{REFERENCES}

1. Vasil'eva O.A. Issledovanie nekotorykh veroyatnostnykh kharakteristik resheniya zadachi Koshi dlya uravneniya Byurgersa-Khaksli [Study of Some Probability Characteristics of the Solution to the Cauchy Problem for the Equation of the BurgersHuxley]. Trudy MAI [Works of Moscow Aviation Institute]. 2014, no. 78. Available at: http://www.mai.ru/science/trudy/. Date of access: 07.07.2015. (In Russian)

2. Vasil'eva O.A. Chislennoe issledovanie sistemy uravneniy Karlemana [Numerical Investigation of the Carleman System] Vestnik MGSU [Proceedings of Moscow State University of Civil Engineering]. 2015, no. 6, pp. 7-15. (In Russian)

3. Andreev V.G., Vasil'eva O.A., Lapshin E.A., Rudenko O.V. Protsessy generatsii vtoroy garmoniki i vyrozhdennogo parametricheskogo usileniya $\mathrm{v}$ srede s selektivnym pogloshcheniem [Processes of Generating the Quadratic Component and Confluent Parametric Amplification in the Environment with Selective Absorption]. Akusticheskiy zhurnal [Acoustic Journal]. 1985, vol. XXXI, no. 1, pp. 12-16. (In Russian)

4. Miller K.S., Ross B. An Introduction to the Fractional Calculus and Fractional Differential Equations. New York, John Wiley and Sons, 1993, 384 p.

5. Aleroev T.S. The Eigenvalues of a Boundary Value Problem for a Fractional-Order Differential Operator. Differential Equations. 2000, vol. 36, no. 10, pp. 1569-1570. DOI: http://dx.doi.org/10.1007/BF02757400.

6. Isaeva L.M., Aleroev T.S. Kachestvennye svoystva odnomernogo drobnogo differentsial'nogo uravneniya advektsii-diffuzii [Qualitative Properties of One-Dimensional Fractional Differential Equation of Advection-Diffusion]. Vestnik MGSU [Proceedings of Moscow State University of Civil Engineering]. 2014, no. 7, pp. 28-33. (In Russian)

7. Savost'yanov V.N., Frishter L.Yu. Modelirovanie kusochno-odnorodnoy zadachi mekhaniki deformiruemogo tverdogo tela [Modeling of Piecewise-Homogeneous Problem of Mechanics of Deformable Solids]. Izvestiya Rossiyskoy akademii nauk. Mekhanika tverdogo tela [A Journal of Russian Academy of Sciences. Mechanics of Solids]. 1993, no. 6, p. 38. (In Russian)

8. Frishter L.Yu. Analiz metodov issledovaniya lokal'nogo napryazhenno-deformirovannogo sostoyaniya konstruktsiy $\mathrm{v}$ zonakh kontsentratsii napryazheniy [Analysis of 
8. Фриштер Л.Ю. Анализ методов исследования локального напряженно-деформированного состояния конструкций в зонах концентрации напряжений // Вестник МГСУ. 2008. № 3. С. 38-44.

9. Фриштер Л.Ю., Мозгалева М.Л. Оценки решения однородной плоской задачи теории упругости в окрестности нерегулярной точки границы // Вестник МГСУ. 2012. № 2. C. $20-24$.

10. Фриштер Л.Ю. Анализ напряженно-деформированного состояния в вершине прямоугольного клина // Вестник МГСУ. 2014. № 5. C. $57-62$.

11. Фриштер Л.Ю. Анализ НДС в зонах концентрации напряжений составных конструкций и машин с применением элементов теории размерности // Проблемы машиностроения и надежности машин. 2008. № 3. С. 37-42.

12. Варданян Г.С., Савостьянов В.Н., Фриштер Л.Ю. Решение задач механики деформируемого твердого тела методом фотоупругости с использованием свойств «Размораживания» // Проблемы машиностроения и надежности машин. 2004. № 2. С. $88-93$.

13. Фриштер Л. Ю., Мозгалева М.Л. Сопоставление возможностей численного и экспериментального моделирования напряженнодеформированного состояния конструкций с учетом их геометрической нелинейности // International Journal for Computational Civil and Structural Engineering. 2010. T. 6. № $1-2$. C. $221-222$.

14. Ларионов Е.К. К вопросу о длительной прочности бетона // Известия высших учебных заведений. Строительство. 2005. № 8 . C. $28-33$.

15. Ларионов E.A. Несущая способность изгибаемого железобетонного элемента при коррозионных повреждениях // Вестник МГСУ. 2014. № 7. C. $51-63$.

16. Ларионов Е.А. Длительное силовое сопротивление и безопасность сооружений : дисс. д-ра техн. наук. М., 2005. 211 с.

17. Ларионов Е.А., Римшин В.И., Василькова Н.Т. Энергетический метод оценки устойчивости сжатых железобетонных элементов // Строительная механика инженерных конструкций и сооружений. 2012. № 2. C. a77-81.
Research Methods of the Local Stress-Strain State of Structures in Zones of Stress Concentration]. Vestnik MGSU [Proceedings of Moscow State University of Civil Engineering]. 2008, no. 3, pp. 38 - 44. (In Russian)

9. Frishter L.Yu., Mozgaleva M.L. Otsenki resheniya odnorodnoy ploskoy zadachi teorii uprugosti v okrestnosti neregulyarnoy tochki granitsy [Evaluations of the Solution to the Homogeneous Two-Dimensional Problem of the Theory of Elasticity in the Vicinity of an Irregular Point of the Border]. Vestnik MGSU [Proceedings of Moscow State University of Civil Engineering]. 2012, no. 2, pp. 20-24. (In Russian)

10. Frishter L.Yu. Analiz napryazhennodeformirovannogo sostoyaniya $\mathrm{v}$ vershine pryamougol'nogo klina [Analysis of Stress-strain State on Top of a Rectangular Wedge]. Vestnik MGSU [Proceedings of Moscow State University of Civil Engineering]. 2014, no. 5, pp. 57-62. (In Russian)

11. Frishter L.Yu. Analiz NDS v zonakh kontsentratsii napryazheniy sostavnykh konstruktsiy i mashin s primeneniem elementov teorii razmernosti [Analysis of the Stress Strain State in the Zones of Stress Concentration for Complex Structures and Machines Using Elements of the Theory of Dimensions]. Problemy mashinostroeniya $i$ nadezhnosti mashin [Problems of Mechanical Engineering and Reliability of Machines]. 2008, no. 3, pp. 37-42. (In Russian)

12. Vardanyan G.S., Savost'yanov V.N., Frishter L.Yu. Reshenie zadach mekhaniki deformiruemogo tverdogo tela metodom fotouprugosti $\mathrm{s}$ ispol'zovaniem svoystv «Razmorazhivaniya» [Solution to the Problems of Deformable Solids Mechanics by the Method of Photoelastic Analysis Using the Properties of "Defrosting"]. Problemy mashinostroeniya $i$ nadezhnosti mashin [Problems of Mechanical Engineering and Reliability of Machines]. 2004, no. 2, pp. 88-93. (In Russian)

13. Frishter L.Yu., Mozgaleva M.L. Sopostavlenie vozmozhnostey chislennogo i eksperimental'nogo modelirovaniya napryazhenno-deformirovannogo sostoyaniya konstruktsiy s uchetom ikh geometricheskoy nelineynosti [Comparison of Possibilities of Numerical and Experimental Modeling of Stress-Strain State of Constructions Taking Into Account Their Geometrical Nonlinearity]. International Journal for Computational Civil and Structural Engineering. 2010, vol. 6, no. 1-2, pp. 221-222. (In Russian)

14. Larionov E.A. K voprosu o dlitel'noy prochnosti betona [To the Problem of Long-Term Strength of Concrete]. Izvestiya vysshikh uchebnykh zavedeniy. Stroitel'stvo [News of Higher Educational Institutions. Construction]. 2005, no. 8, pp. 28-33. (In Russian)

15. Larionov E.A. Nesushchaya sposobnost' izgibaemogo zhelezobetonnogo elementa pri korrozionnykh povrezhdeniyakh [Bearing Capacity of Corroded Bending Reinforced Concrete Element]. Vestnik MGSU [Proceedings of Moscow State University of Civil Engineering]. 2014, no. 7, pp. 5163. (In Russian)

16. Larionov E.A. Dlitel'noe silovoe soprotivlenie i bezopasnost' sooruzheniy : dissertatsiya ... doktora tekhnicheskikh nauk [Continuous Resistance and Safety of Structures : dissertation of the Doctor of Technical Sciences]. Moscow, 2005. 211 p. (In Russian)

17. Larionov E.A.,Rimshin V.I., Vasil'kova N.T. Energeticheskiy metod otsenki ustoychivosti szhatykh zhelezobetonnykh elementov [Energy Method for Assessing the Re- 
18. Гринченко В.Т., Улитко А.Ф., Шульга Н.А. Механика связанных полей в элементах конструкций. Киев : Наукова Думка, 1989. Т. 5. Электроупругость. 278 с.

19. Бобылева Т.Н. Распространение осесимметричных волн в пьезокерамических цилиндрах // Вестник МГСУ. 2007. № 1. С. 23-26.

20. Бобылева Т.Н. Определение резонансных частот осесимметричных колебаний полого шара с использованием уравнений движения трехмерной теории упругости // Вестник МГСУ. 2015. № 7. C. $25-32$.

21. Kir'yanova L.V., Rotar' V.I. Some remarks on sums of dependent components // Mathematical Notes. 1987. Vol. 42. No. 5. Pp. 910-912.

22. Kir'yanova L.V. Nonclassical estimates of precision of normal approximation for Martingales // Mathematical Notes. 1992. Vol. 52. No. 5. Pp. 1116-1120.

23. Kir'yanova L.V., Kabanov K.I. Some aspects of modeling a random process on the spectral density method of canonical expansions // Integration processes and innovative technologies. Achievements and prospects of engineering sciences. Collection of sciences works. Kharkiv, 2012. Issue 2. Pp. 248-251.

24. Кирьянова Л.В., Усманов А.Р. Оценка спектральной плотности аэродинамического коэффициента лобового сопротивления // Вестник МГСУ. 2012. № 10. С. 88-94.

25. Кирьянова Л.В., Мачеевич T.A. О необходимости введения дисциплины «Математическая статистика» для магистров, обучающихся по направлению 270800 «Строительство» // Теоретические и методологические проблемы современного образования : материалы XVII Междунар. науч.-практ. конф. (г. Москва, 25-26 декабря 2014 г.). М. : Изд-во «Спецкнига», 2014. C. 89-91.

26. Kartashov G.D., Chiganova N.M. Construction of control plans using a quantitative index with twosided bounds // Journal of Mathematical Sciences. 1987. Vol. 39. No. 2. C. $2578-2588$.

27. Чиганова Н.М. Логарифмическая выпуклость по параметру некоторых распределений // Естественные и технические науки. 2015. № 6 (84). С. 49-51.

28. Медведев В.В., Чиганова H.M. Оценка надежности изделий sistance of Compressed Reinforced Concrete Elements]. Stroitel'naya mekhanika inzhenernykh konstruktsiy $i$ sooruzheniy [Structural Mechanics of Engineering Constructions and Buildings]. 2012, no. 2, pp. a77-81. (In Russian)

18. Grinchenko V.T., Ulitko A.F., Shul'ga N.A. Mekhanika svyazannykh poley $v$ elementakh konstruktsii [Mechanics of Connected Fields in Structural Elements]. Kiev, Naykova Dumka, 1989, vol. 5. Electroelasticity. 278 p. (In Russian)

19. Bobyleva T.N. Rasprostranenie osesimmetrichnykh voln v p'ezokeramicheskikh tsilindrakh [Propagation of Axisymmetric Waves in a Piezoceramic Cylinders]. Vestnik $M G S U$ [Proceedings of Moscow State University of Civil Engineering]. 2007, no. 1, pp. 23-26. (In Russian)

20. Bobyleva T.N. Opredelenie rezonansnykh chastot osesimmetrichnykh kolebaniy pologo shara s ispol'zovaniem uravneniy dvizheniya trekhmernoy teorii uprugosti [Determination of Resonant Frequencies of Axisymmetric Oscillations of a Hollow Ball Using of the Equations of Motion of ThreeDimensional Elasticity Theory]. Vestnik MGSU [Proceedings of Moscow State University of Civil Engineering]. 2015, no. 7, pp. 25-32. (In Russian)

21. Kir'yanova L.V., Rotar' V.I. Some Remarks on Sums of Dependent Components. Mathematical Notes. 1987, vol. 42, no. 5, pp. 910—912. DOI: http://dx.doi.org/10.1007/ BF01137439.

22. Kir'yanova L.V. Nonclassical Estimates of Precision of Normal Approximation for Martingales. Mathematical Notes. 1992, vol. 52, no. 5, pp. 1116-1120. DOI: http://dx.doi.org/10.1007/BF01236619.

23. Kir'yanova L.V., Kabanov K.I. Some Aspects of Modeling a Random Process on the Spectral Density Method of Canonical Expansions. Integration Processes and Innovative Technologies. Achievements and Prospects of Engineering Sciences. Collection of Sciences Works. Kharkiv, 2012, no. 2, pp. $248-251$.

24. Kir'yanova L.V., Usmanov A.R. Otsenka spektral'noy plotnosti aerodinamicheskogo koeffitsienta lobovogo soprotivleniya [Assessment of Spectral Density of the Aerodynamic Factor of Front Resistance]. Vestnik MGSU [Proceedings of Moscow State University of Civil Engineering]. 2012, no. 10, pp. 88-94. (In Russian)

25. Kir'yanova L.V., Matseevich T.A. O neobkhodimosti vvedeniya distsipliny «Matematicheskaya statistika» dlya magistrov, obuchayushchikhsya po napravleniyu 270800 «Stroitel'stvo» [On the Necessity of Introduction of the Discipline "Mathematical Statistics" for Master Students of the Specialty 270800 "Construction"]. Teoreticheskie i metodologicheskie problemy sovremennogo obrazovaniya : materialy XVII Mezhdunarodnoy nauchno-prakticheskoy konferentsii (g. Moskva, 25-26 Dekabrya 2014 g.) [Theoretical and Methodological Problems of Modern Education. Proceedings of the XVIIth International Scientific and Practical Conference (Moscow, December 25-26, 2014)]. Moscow, «Spetskniga» Publ., 2014, pp. 89-91. (In Russian)

26. Kartashov G.D., Chiganova N.M. Construction of Control Plans Using a Quantitative Index with Two-Sided Bounds. Journal of Mathematical Sciences. 1987, vol. 39, no. 2, pp. 2578-2588. DOI: http://dx.doi.org/10.1007/ BF01084966.

27. Chiganova N.M. Logarifmicheskaya vypuklost' po parametru nekotorykh raspredeleniy [Logarithmic Convexity on the Parameter of Some Distributions]. Estestvennye $i$ 
по результатам программных испытаний // Научное обозрение. 2015. № 14. C. $232-235$.

29. Титова Т.Н. Производные векторнозначных мер // Известия высших учебных заведений. Математика. 1979. № 6. С. 58-65.

30. Титова Т.Н. Производная функции, и ее применение в инженерном вузе: учеб. пособие. М. : МГСУ, 2010. $80 \mathrm{c}$

31. Титова T.Н. О нахождении нормального вида гамильтоновых матриц // Прикладная математика и механика. 1981. Т. 45. № 6 . C. $1026-1031$.

32. Титова T.Н. Свойства гамильтоновых матриц // Естественные и технические науки. 2015. № 6 (84). С. 65-66.

33. Титова T.Н. О нормализации линейных гамильтоновых систем // Вопросы математики, механики сплошных сред и применения математических методов в строительстве : сб. науч. тр. М. : МГСУ, 2010. Вып. 12. С. $78-85$.

34. Титова T.Н. О нормализации линейной гамильтоновой системы с помощью канонических преобразований. Деп. в ВИНИТИ № 1049-76, 05.04.76.

35. Осиленкер Б.П. Ряды Фурье по нагруженным ортогональным полиномам // Вестник МГСУ. 2013. № 8. C. $35-41$.

36. Осиленкер Б.П. О некоторых экстремальных задачах для алгебраических полиномов в нагруженных пространствах // Известия высших учебных заведений. Математика. 2010. № 2. С. 53-65.

37. Osilenker B.P. Generalized trace formula and asymptotics of the averaged Turan determinant for polynomials orthogonal with a discrete Sobolev inner product // Journal of Approximation Theory. 2006. Vol. 141. No. 1. Pp. 70-97.

38. Осиленкер Б.П. Симметричные полиномы Лежандра-Соболева в пространствах ПонтрягинаСоболева // Журнал математической физики, анализа, геометрии. 2002. T. 3. № 3. C. $385-393$.

39. Кузина Т.С. Экстремальные задачи для аналитических функций классов Харди - Соломенцева в многосвязных областях // Известия вузов. Математика. 1987. № 8 (300). C. $30-39$.

40. Кузина Т.С. Об одном классе экстремальных задач, относя- tekhnicheskie nauki [Natural and Technical Sciences]. 2015, no. 6 (84), pp. 49-51. (In Russian)

28. Medvedev V.V., Chiganova N.M. Otsenka nadezhnosti izdeliy po rezul'tatam programmnykh ispytaniy [Assessment of the Reliability of Products according to the Results of Software Testing]. Nauchnoe obozrenie [Scientific Review]. 2015, no. 14, pp. 232-235. (In Russian)

29. Titova T.N. Proizvodnye vektornoznachnykh mer [Derivatives of Vector Value Measures]. Izvestiya vysshikh uchebnykh zavedeniy. Matematika [Russian Mathematics (Iz. VUZ)]. 1979, no. 6, pp. 58-65. (In Russian)

30. Titova T.N. Proizvodnaya funktsii $i$ ee primenenie $v$ inzhenernom vuze : uchebnoe posobie [Derivative of Function and its Application in an Engineering University. Training Manual]. Moscow, MGSU Publ., 2010, 80 p. (In Russian)

31. Titova T.N. O nakhozhdenii normal'nogo vida gamil'tonovykh matrits [On Finding the Normal Form of Hamiltonian Matrices]. Prikladnaya matematika i mekhanika [Applied Mathematics and Mechanics]. 1981, vol. 45, no. 6, pp. 1026-1031. (In Russian)

32. Titova T.N. Svoystva gamil'tonovykh matrits [Properties of Hamiltonian Matrices]. Estestvennye i tekhnicheskie nauki [Natural and Technical Sciences]. 2015, no. 6 (84), pp. 65-66. (In Russian)

33. Titova T.N. O normalizatsii lineynykh gamil'tonovykh sistem [On Normalization of Linear Hamiltonian Systems]. Voprosy matematiki, mekhaniki sploshnykh sred $i$ primeneniya matematicheskikh metodov $v$ stroitel'stve : sbornik nauchnykh trudov [Issues in Mathematics, Continuum Mechanics and Applications of Mathematical Methods in the Construction. Collection of Scientific Papers]. Moscow, MGSU Publ., 2010, no. 12, pp. 78-85. (In Russian)

34. Titova T.N. $O$ normalizatsii lineynoy gamil'tonovoy sistemy s pomoshch'yu kanonicheskikh preobrazovaniy [On Normalization of the Linear Hamiltonian System Using a Canonical Transformations]. Moscow, 1976, Deposited manuscript no. 1049-76, 05.04.76. (In Russian)

35. Osilenker B.P. Ryady Fur'e po nagruzhennym ortogonal'nym polinomam [Fourier Series in Respect of Loaded Orthogonal Polynomials]. Vestnik MGSU [Proceedings of Moscow State University of Civil Engineering]. 2013, no. 8, pp. 35-41. (In Russian)

36. Osilenker B.P. O nekotorykh ekstremal'nykh zadachakh dlya algebraicheskikh polinomov v nagruzhennykh prostranstvakh [On Particular Extremum Problems for Algebraic Polynomials in Loaded Spaces]. Izvestiya vysshikh uchebnykh zavedeniy. Matematika [Russian Mathematics (Iz. VUZ)]. 2010, no. 2, pp. 53-65. (In Russian)

37. Osilenker B.P. Generalized Trace Formula and Asymptotics of the Averaged Turan Determinant for Polynomials Orthogonal with a Discrete Sobolev Inner Product. Journal of Approximation Theory. 2006, vol. 141, no. 1, pp. 70-97. DOI: http://dx.doi.org/10.1016/j.jat.2005.11.019.

38. Osilenker B.P. Simmetrichnye polinomy LezhandraSoboleva v prostranstvakh Pontryagina-Soboleva [Symmetric Polynomials of Legendre-Sobolev in Pontryagin-Sobolev Spaces]. Zhurnal matematicheskoy fiziki, analiza, geometrii [Journal of Mathematical Physics, Analysis, Geometry]. 2002, vol. 3, no. 3, pp. 385-393. (In Russian)

39. Kuzina T.S. Ekstremal'nye zadachi dlya analiticheskikh funktsiy klassov Khardi - Solomentseva v mnogosvyaznykh oblastyakh [Extremum Problems for Analytic Functions of Hardy-Solomentsev Classes in Multiply Connect- 
щихся к проблеме моментов // Ученые записки Ереванск. ун-та. Естеств. науки. 1984. № 2. С. 3-10.

41. Khavinson S.Ya., Kuzina T.S

The structural formulae for extremal functions in hardy classes on finite riemann surfaces // Operator theory advances and applications. Selected Topics in Complex Analysis. The S.Ya. Khavinson Memorial Volume. Birkauser Verlag. 2005. Pp. 37-58.

42. Овчинцев М.П., Гусакова E.M. Вычисление коэффициентов линейного наилучшего метода восстановления ограниченных аналитических функций в круге // Вестник МГСУ. 2014. № 4. С. 44-51.

43. Овчинцев М.П. Конформная инвариантность задач оптимального восстановления производных от ограниченных функций // Строительство: наука и образование. 2015. № 2. Ст. 1. Режим доступа http://www.nso-

journal.ru/public/journals/1/issues/201 5/02/1_Ovchintsev.pdf.

44. Овчинцев М.П., Овчинцев E.M. Об одной экстремальной задаче в двусвязной области // Естественные и технические науки. 2014. № 9-10 (77). C. 20-22.

45. Овчинцев М.П., Овчинцев E.M. Об оптимальном восстановлении первых производных аналитических ограниченных функций в круге // Естественные и технические науки. 2015. № 3 (81). С. 19-21.

46. Lemin A.Yu., Smirnov Yu.M. Isometry groups of metric and ultrametric spaces and their subgroups // Russian Mathematical Surveys. 1986. Vol. 41. No. 6. Pp. 213-218.

47. Lemin A.J., Lemin V. On a universal ultrametric space // Topology and its applications. 2000, vol. 103 , no. 3. Pp. 339-345.

48. Lemin A.J. Spectral decomposition of ultrametric spaces and topos theory // Topology proceedings. 20012002. Vol. 26, no. 2. Pp. 721-739.

49. Lemin A.J.. On ultrametrization of general metric spaces // Proceedings of the American mathematical society. 2002. Vol. 131. No. 3. Pp. 979-989.

50. Мясников А.Г. Об абсолютной непрерывности норм в банаховых идеальных пространствах со сдвигами // Известия высших учебных заведений. Математика. 1990. № 3. С. $78-80$.

51. Мясников А.Г. Аменабельные банаховы $L_{1}(G)$-модули, инва- ed Domains]. Izvestiya vuzov. Matematika [Russian Mathematics (Iz. VUZ)]. 1987, no. 8 (300), pp. 30-39. (In Russian)

40. Kuzina T.S. Ob odnom klasse ekstremal'nykh zadach, otnosyashchikhsya k probleme momentov [On a Class of Extremum Problems Related to the Moment Problem]. Uchenye zapiski Erevanskogo universiteta. Estestvennye nauki [Proceedings of the Yerevan University. Natural Sciences]. 1984, no. 2, pp. 3-10. (In Russian)

41. Khavinson S.Ya., Kuzina T.S. The Structural Formulae for Extremal Functions in Hardy Classes on Finite Riemann Surfaces. Operator Theory Advances and Applications. Selected Topics in Complex Analysis. Operator Theory Advances and Applications. Selected Topics in Complex Analysis. The S.Ya. Khavinson Memorial Volume. Birkauser Verlag, 2005, pp. 37-58. DOI: http://dx.doi.org/10.1007/37643-7340-7_4.

42. Ovchintsev M.P., Gusakova E.M. Vychislenie koeffitsientov lineynogo nailuchshego metoda vosstanovleniya ogranichennykh analiticheskikh funktsiy $\mathrm{v}$ kruge [Coefficients Calculation of the Best Linear Method for Recovery of Bounded Analytic Functions in a Circle.]. Vestnik MGSU [Proceedings of Moscow State University of Civil Engineering]. 2014, no. 4, pp. 44-51. (In Russian)

43. Ovchintsev M.P. Konformnaya invariantnost' zadach optimal'nogo vosstanovleniya proizvodnykh ot ogranichennykh funktsiy [Conformal Invariance of the Optimal Renewal Tasks of the Derivatives from the Confined Analytic Functions]. Stroitel'stvo: nauka i obrazovanie [Construction: Science and Education]. 2015, no. 2, Article 1. Available at: http://www.nso-journal.ru/public/journals/1/issues/2015/02/1 _Ovchintsev.pdf.

44. Ovchintsev M.P., Ovchintsev E.M. Ob odnoy ekstremal'noy zadache v dvusvyaznoy oblasti [On One Extremal Problem in Doubly Connected Region]. Estestvennye $i$ tekhnicheskie nauki [Natural and Technical Sciences]. 2014, no. 9-10 (77), pp. 20-22. (In Russian)

45. Ovchintsev M.P., Ovchintsev E.M. Ob optimal'nom vosstanovlenii pervykh proizvodnykh analiticheskikh ogranichennykh funktsiy v kruge [On Optimal Recovery of First Derivatives of Analytic Bounded Functions in the Circle]. Estestvennye $i$ tekhnicheskie nauki [Natural and Technical Sciences]. 2015, no. 3 (81), pp. 19-21. (In Russian)

46. Lemin A.Yu., Smirnov Yu.M. Isometry Groups of Metric and Ultrametric Spaces and Their Subgroups. Russian Mathematical Surveys. 1986, vol. 41, no. 6, pp. 213-218.

47. Lemin A.J., Lemin V. On a Universal Ultrametric Space. Topology and its Applications. 2000, vol. 103, no. 3, pp. 339-345. DOI: http://dx.doi.org/10.1016/S01668641(99)00029-2.

48. Lemin A.J. Spectral Decomposition of Ultrametric Spaces and Topos Theory. Topology Proceedings. 20012002, vol. 26, no. 2, pp. 721-739.

49. Lemin A.J. On Ultrametrization of General Metric Spaces. Proceedings of the American Mathematical Society. 2002, vol. 131, no. 3, pp. 979-989.

50. Myasnikov A.G. Ob absolyutnoy nepreryvnosti norm v banakhovykh ideal'nykh prostranstvakh so sdvigami [On Absolute Continuity of Norms in Banach Ideal Spaces with Shifts]. Izvestiya vysshikh uchebnykh zavedeniy. Matematika [Russian Mathematics (Iz. VUZ)]. 1990, no. 3, pp. 78-80. (In Russian)

51. Myasnikov A.G. Amenabel'nye banakhovy $L_{1}(G)$ moduli, invariantnye srednie i regulyarnost' v smysle Arensa 
риантные средние и регулярность в смысле Аренса // Известия высших учебных заведений. Математика. 1993. № 2 (369). С. $72-80$.

52. Мясников А.Г. Операторные алгебры и аппроксимативные диагонали // Вестник МГСУ. 2013. № 9. C. $16-22$.

53. Мясников А.Г. О предпорядках, определяемых компонентой аменабельности в $L^{\infty}(G)$ // Естественные и технические науки. 2015. № 3 (81). C. 13-15.

54. Matseevich T., Askadskii A. The dependence of the modulus of elasticity on the concentration of plasticizer // Applied Mechanics and Materials. 2014. Vol. 584-586. Pp. 1709-1713.

55. Мацеевич Т.A., Попова М.Н., Володина А.Е., Аскадский А.А. Влияние размера частиц на модуль упругости смесей полимеров // Вестник МГСУ. 2014. № 8. С. 73-90.

56. Мачеевич Т.A., Попова М.Н., Мацеевич А.B., Казаниева В.В., Коврига О.В., Аскадский А.А. Релаксационные свойства композиционного материала на основе полипропилена, содержащего асбест в качестве наполнителя // Пластические массы 2014. № 5-6. С. 50-53.

57. Аскадский А.А., Мацеевич Т.А., Попова М.Н., Кондращченко В.И. Прогнозирование совместимости полимеров, анализ состава микрофаз и ряда свойств смесей // Высокомолекулярные соединения. Серия А. 2015. Т. 57. № 2. С. $162-175$.

58. Smirnov M.I., Khajrullin R.Z. A control system for goods delivery with the use of intermediate warehouses // Известия Российской академии наук. Теория и системы управления. 2002. № 5. С. 146-152.

59. Хайруллин Р.3. К исследованию маневренных возможностей экскаватора-драглайна // Вестник МГСУ. 2010. № 4-3. С. 49-53.

60. Хайруллин P.3. Математическое моделирование развоза грузов по разветвленной сети автодорог // Вестник МГСУ. 2014. № 7. С. 184-191.

61. Хайруллин Р.3. Система оперативного управления складской логистикой металлоторгующих компаний // Вестник МГСУ. 2014. № 6. С. $172-178$.

62. Селина В.О., Ассеева Е.Е. Возможности дистанционной самостоятельной подготовки студентов с помощью презентаций в курсе математики // Проблемы современной
[Amenable Banach $L_{1}(G)$-modules, Invariant Average and Regularity in the Sense of Arens]. Izvestiya vysshikh uchebnykh zavedeniy. Matematika [Russian Mathematics (Iz. VUZ)]. 1993, no. 2 (369), pp. 72-80. (In Russian)

52. Myasnikov A.G. Operatornye algebry i approksimativnye diagonali [Operator Algebras and Approximate Diagonals]. Vestnik MGSU [Proceedings of Moscow State University of Civil Engineering]. 2013, no. 9, pp. 16-22. (In Russian)

53. Myasnikov A.G. O predporyadkakh, opredelyaemykh komponentoy amenabel'nosti v $L^{\infty}(G)$ [On Preorders Defined Component of Amenability in $\left.L^{\infty}(G)\right]$. Estestvennye $i$ tekhnicheskie nauki [Natural and Technical Sciences]. 2015, no. 3 (81), pp. 13-15. (In Russian)

54. Matseevich T., Askadskii A. The Dependence of the Modulus of Elasticity on the Concentration of Plasticizer. Applied Mechanics and Materials. 2014, vol. 584-586, pp. 1709-1713. DOI: http://dx.doi.org/10.4028/www.scientific. net/AMM.584-586.1709.

55. Matseevich T.A., Popova M.N., Volodina A.E., Askadskiy A.A. Vliyanie razmera dispersnykh chastits na modul' uprugosti smesey polimerov [Influence of Disperse Particles on the Modulus of Elasticity of Polymer Blends]. Vestnik MGSU [Proceedings of Moscow State University of Civil Engineering]. 2014, no. 8, pp. 73-90.

56. Matseevich T.A., Popova M.N., Matseevich A.V., Kazantseva V.V., Kovriga O.V., Askadskiy A.A. Relaksatsionnye svoystva kompozitsionnogo materiala na osnove polipropilena, soderzhashchego asbest $\mathrm{v}$ kachestve napolnitelya [Relaxation Properties of Composite Material Based on Polypropylene Containing Asbestos as a Filler]. Plasticheskie massy [Plastic Materials]. 2014, no. 5-6, pp. 50-53. (In Russian)

57. Askadskiy A.A., Matseevich T.A., Popova M.N., Kondrashchenko V.I. Prognozirovanie sovmestimosti polimerov, analiz sostava mikrofaz i ryada svoystv smesey [Predicting Compatibility of Polymers, Analysis of the Composition of Micro-Phases and Some Properties of Mixtures]. Vysokomolekulyarnye soedineniya. Seriya A [High-molecular Compounds. Series A]. 2015, vol. 57, no. 2, pp. 162-175. (In Russian)

58. Smirnov M.I., Khajrullin R.Z. A Control System for Goods Delivery with the Use of Intermediate Warehouses. Izvestiya Rossiyskoy akademii nauk. Teoriya i sistemy upravleniya [News of RAS. Theory and Control Systems]. 2002, no. 5, pp. 146-152. (In Russian)

59. Khayrullin R.Z. K issledovaniyu manevrennykh vozmozhnostey ekskavatora-draglayna [To Study of Maneuvering Capabilities of the Dragline]. Vestnik MGSU [Proceedings of Moscow State University of Civil Engineering]. 2010, no. 4-3, pp. 49-53. (In Russian)

60. Khayrullin R.Z. Matematicheskoe modelirovanie razvoza gruzov po razvetvlennoy seti avtodorog [Mathematical Simulation of the Cargoes Delivery on an Extensive Network of Automobile Roads]. Vestnik MGSU [Proceedings of Moscow State University of Civil Engineering]. 2014, no. 7, pp. 184-191. (In Russian)

61. Khayrullin R.Z. Sistema operativnogo upravleniya skladskoy logistikoy metallotorguyushchikh kompaniy [Operational Management System for Warehouse Logistics of Metal Trafing Copmanies]. Vestnik MGSU [Proceedings of Moscow State University of Civil Engineering]. 2014, no. 6, pp. 172-178. (In Russian) 
науки и образования. 2015. № 5 (35). C. $87-90$.

63. Медведева Н.А. Индивидуальный подход в обучении базовым курсам в техническом вузе // Actualscience. 2015. T. 1. № 1 . C. $42-43$.

64. Медведева Н.А. Индивидуально-дифференцированный подход в обучении высшей математике студентов технического вуза // Проблемы современной науки и образования. 2015. № 10 (40). С. 141-143.

Поступила в редакциию в сентябре 20152.
62. Selina V.O., Asseeva E.E. Vozmozhnosti distantsionnoy samostoyatel'noy podgotovki studentov $\mathrm{s}$ pomoshch'yu prezentatsiy v kurse matematiki [Remote Independent Preparation of Students Using Presentations in the Course of Mathematics]. Problemy sovremennoy nauki $i$ obrazovaniya [Problems of Modern Science and Education]. 2015, no. 5 (35), pp. 87-90. (In Russian)

63. Medvedeva N.A. Individual'nyy podkhod v obuchenii bazovym kursam v tekhnicheskom vuze [Individual Approach in Teaching Higher Mathematics in Technical University]. Actualscience. 2015, vol. 1, no. 1, pp. 42-43. (In Russian)

64. Medvedeva N.A. Individual'no-differentsirovannyy podkhod v obuchenii vysshey matematike studentov tekhnicheskogo vuza [Individually-Differentiated Approach in Teaching Higher Mathematics to the Students of a Technical University]. Problemy sovremennoy nauki i obrazovaniya [Problems of Modern Science and Education]. 2015, no. 10 (40), pp. 141-142. (In Russian)

Received in September 2015.
Об авторе: Бобылева Татьяна Николаевна, кандидат физико-математических наук, доцент, доцент кафедры высшей математики,

Национальный исследовательский Московский государственный строительный университет (НИУ МГСУ), 129337, Г. Москва, Ярославское шоссе, д. 26, 8 (499) 18330-38, tatyana2211@ outlook.com.
About the author: Bobyleva Tat'yana Nikolaevna, Candidate of Physical and Mathematical Sciences, Associate Professor, Department of Higher Mathematics, Moscow State University of Civil Engineering (MGSU), 26 Yaroslavskoe shosse, Moscow, 129337, Russian Federation; +7 (499) 183-3038, tatyana2211@outlook.com.

Для цитирования:

Бобылева Т.Н. Актуальные прикладные исследования кафедры высшей математики МГСУ // Строительство: наука и образование. 2015. № 4. Ст. 2. Режим доступа: http://nso-journal.ru.

For citation:

Bobyleva T.N. Aktual'nye prikladnye issledovaniya kafedry vysshey matematiki MGSU [Current applied investigations of the Department of Higher Mathematics of MGSU]. Stroitel'stvo: nauka i obrazovanie [Construction: Science and Education]. 2015, no. 4, paper 2. Available at http://nso-journal.ru. (In Russian) 